\title{
Analysis and Use of Figures of Speech
}

\section{- Lok Raj Regmi}

\begin{abstract}
Poetry, a form of literature, displays varieties of language use through figures of speech, the rhetorical devices. There are two views for and against the use of such rhetorical devices in language teaching. One of the views shows its strong resentment in using such figures of speech and does not find the space of them in language teaching whereas the next speaks in favour of using them in language teaching if the texts are wisely selected. It is the judicious or creative use of figures of speech. A language teacher tries to look at them from language teaching point of view. This writing primarily analyzes the representative figures of speech, states some examples with their language features and ultimately justifies how figures of speech support language teaching and learning.
\end{abstract}

Key words: Figures of speech, poetry, deviated language, indirect and connotative language, language teaching

\section{General Introduction}

Poetry, mostly composed in verse, is a written discourse. It is one of the effective forms of literature to express human ideas, emotions, reactions, responses, etc. In the words of Wordsworth (as cited in Nayar, 2009, p. 194), "Poetry is a spontaneous overflow of powerful feelings recollected in tranquility". Poetry primarily is an expression of the state of human mind. Since poetry is often regarded as a medium for the expression of subjective, personal eventsan assumption which does not always correspond to the facts-the issue of the speaker is central to the analysis of poem.

The use of figures of speech, rearranged syntax and the dominance of prosodic features (except in free verse) distinguishes poetry from other literary senses especially from prose. For example, Elegy Written in country Churchyard (1751), which deals with human transitoriness, uses concrete images: a cemetery, the ringing of bell, a farmer returning from tilling, darkness, and tomb stones. Such objects and expressive scenes are described to make the poem concrete. Consequently, poetry becomes a piece of writing in which words are arranged /chosen for their sound and for the images, ideas they suggest.

In the words of Throad (2004, p. 2), "Since poets have to express the intensity of their experience with a minimum number of words, the language of poetry has to be very precise". That is why a text of poem can be a spicy material to a single classroom lesson. Collie (2009, p. 226) rightly says, "There is the initial advantage of length- 
many poems are well-suited to a single classroom lesson".

Since poetry naturally allows the varieties of language use along with the figures of speech, it avails the readers/learners with several opportunities to play with the language use, to pull it this way and that, to test its elasticity, to explore its limits. For example, the coinage of new words, creation of new collocations, the use of old words in new ways, the use of same word(s) for difference purposes/meanings, the connotative use of words, etc.

In poetry, either subjective feelings of poet or his/her description on objects can be expressed using figures of speech. They can be more effective means or vehicles to express, expand and explore the emotion, imagination and observation of poets. Further, figures of speech, rearranged syntax in poems can pinpoint the area for ample attention; make the expression memorable apart from developing readers'/ learners' linguistic competence.

\section{Figures of speech}

Figures of speech basically deal with the vehicles which primarily make the expression of language more beautiful and effective. In a traditional way, these devices have been described as poetic ornaments in a traditional way of analyzing the poem. The author in poetry, using these devices; metaphors, images, symbols, personification, etc. can deliver the message indirectly to the readers. As a result language becomes connotative and or referential. As we look at these figures of speech from linguistics point of view, we find them full of language features. Supporting this view, Gautam (2014) points out, "A figure of speech is a way of saying something other than the literal way. It adds extra dimensions to language and reveals one thing by relating it to something else".

In the words of Gray (2008, p. 120) "Any form of expression or grammar which deviates from the plainest expression of meaning is designated a figure of speech". This writing attempts to analyze representative figures of speech and presents how such figurative language of poetry supports learners in fostering their linguistic competence.

\section{Representative figures of speech}

In this section, some of the representative types of figures of speech have been introduced (see analysis section for the examples.)

a. Allegory and Circumlocution: An Allegory is a story in verse or in prose with a double meaning: a primary or surface meaning and a secondary or referential meaning. Circumlocution is an indirect way of speaking.

b. Euphemism: Euphemism is the use of pleasant, mild and indirect words instead of more precise and direct ones. In the words of Abrams (2005, p. 88), "Euphemism is an inoffensive expression used in place of a blunt one that is felt to be disagreeable".

c. Irony and satire: The difference between what is told and what is done is irony. According to Gray (2008, p. 255), "A satire exhibits or examines vice and folly and makes them appear ridiculous". Irony and satire are used in both prose and poetry.

d. Metaphor and simile: Metaphor and simile refer to comparison between two dissimilar objects with their common qualities. The former one is implied and indirect comparison whereas the latter one is direct comparison. 
e. Metonymy and synecdoche: Metonymy in writing is the substitution of the name of a thing through attribution or association. Synecdoche is a figure of speech in which a part refers to the whole of something or vice versa.

f. Paradox and parody: A statement that seems to be absurd or contradictory but is/may be true is paradox. Supporting this view, Abrams (2005, p. 209) writes, "The paradox used occasionally by almost all poets (although it is a central feature of metaphysical poets) is a statement which seems on its face to be logically contradictory, yet turns out to be interpretable in a way that makes sense". Parody is a piece of speech or writing that imitates the style of others either exactly or in an exaggerated way.

g. Personification and pleonasm: Treating something without life as a human being or representing it in human form i.e. (human attributes and feeling) is personification. Pleonasm has the use of unnecessary syntactic addition, more words than necessary have been used to express the meaning.

h. Oxymoron and conceit: From linguistic point of view, oxymoron allows the combination of two contradictory terms. According to Cuddon (1982, p. 47), "It is a figure of speech which combines incongruous and apparently contradictory words and meanings for a special effect". A conceit, as its distinguished quality, forges an unexpected comparison between two apparently dissimilar ideas.

i. Allusion and anaphora: In an allusion, we get the reference of place, event especially from the previous literary works either directly or through implication. Anaphora is a particular figure of speech consisting sequence of repeated words at the beginning of neighboring clauses to create emphasis.

j. Image and symbol: An image signifies figurative language, especially the vehicle of metaphors and similes. It describes the quality of an object. A symbol can be an object that represents an abstract idea: love, hatred, tragedy, unionism, death, etc.

\section{Textual examples of figures of speech}

This section presents some examples of figures of speech used in different texts of poetry.

1. The broken wall, the burning roof and tower, And Agamemnon dead.

(W.B Yeats in Leda and the Swan)

2. When the stars threw down their spears And watered heaven with their tears

Did he smile his work to see

Did he who made the Lamb make thee?

(William Blake in The Tyger)

3. Thou by the Indian Ganges' side

I by the tide of Humber would complain.

(Andrew Marvell in to His Coy Mistress)

4. The throwers throw only now and then, But the gatherers

Continue with their hoarding forever.

(Prakash Subedi in At the Temple)

5. Was he free? Was he happy?

The question is absurd:

Had anything been wrong? We

Certainly should have heard.

(W.H Auden in The Unknown Citizen)

6. My vegetable love should grow, Vaster than empires, and more slow.

(Andrew Marvell in To His Coy Mistress)

7. It is an ever fixed mark, That looks an tempest and is never shaken, 
It is the star to every wandering bark. (William Shakespeare in Marriage of True Minds)

8. This city now doth, like a garment, wear The beauty of the morning; silent bare.

(William Wordsworth in Composed upon Westminster Bridge)

9. My manhood is cast down

I weep like a child for the past.

(D. H. Lawrence in Piano)

10. O Rose, thou art sick:

The invisible worm,

That flies in the night

In the howling storm.

(William Blake in The Sick Rose)

11. Ten thousand I saw at a glance,

Tossing their hands in sprightly dance.

(William Wordsworth in Daffodils)

12. Steady thy laden head across a brook, Or by a cider-press, with patient look, Thou watchest the last oozings, hours by hours.

(John Keats in Ode to Autumn)
13. The stationary blasts of waterfalls, Tumult and peace, the darkness and the light.

(William Wordsworth in The Prelude)

14. Deep as first love, and wild with all regret: O Death in life, the days that are no more. (Alfred L. Tennyson in Tears, Idle Tears)

15. A hundred years should go to praise Thine eyes, and on thy forehead gaze Two hundred to adore each breast, But thirty thousand to the rest (Andrew Marvell in To His Coy Mistress)

16. And swear

No where

Lives a woman true and fair (John Donne in Songs)

17. In time the savage bull sustains the yoke, In time all haggard hawks will stop to lure. (Thomas kyd in The Spanish Tragedy)

18. And miles to go before I sleep, And miles to go beforeI sleep (Robert Frost in Stopping by Woods in a Snowy Evening)

Table 1

\begin{tabular}{|c|l|c|l|}
\hline S.No. & \multicolumn{1}{|c|}{ Figures of speech } & Example No. & \multicolumn{1}{c|}{ Effects } \\
\hline 1. & Metaphor and simile & $6,7,8,9$ & Varieties of language use, motivating language \\
\hline 2. & Irony and satire & 4,5 & $\begin{array}{l}\text { Provides the students with space for discussion, } \\
\text { critical thinking, and creative writing }\end{array}$ \\
\hline 3. & Allusion & $1,2,3$ & Reference from the past events. \\
\hline 4. & Image and symbol & 10,12 & Pictorial, vivid and poetic language. \\
\hline 5. & $\begin{array}{l}\text { Personification and } \\
\text { paradox }\end{array}$ & $8,9,11,12$ & $\begin{array}{l}\text { Example of deviation, the language departs from } \\
\text { the ordinary mode of communication. Rearranged } \\
\text { syntax can develop language awareness }\end{array}$ \\
\hline 6. & Oxymoron and conceit & 13,14 & Poetic effects, focus on meanings, motivating language \\
\hline 7. & Exaggeration/hyperbole & 15,16 & The tone of epigram, appeal for attention \\
\hline 8. & Anaphora and refrain & 17,18 & Distinctive effects, pleasing sound, motivating language \\
\hline
\end{tabular}

\section{Conclusion}

Poetry, a form of literature, displays various examples of figures of speech. Such figures of speech like: metaphor and simile; irony and satire; image and symbol; personification and paradox; anaphora and refrain, etc. make the 
language indirect, connotative, and deviated. Does this variety of language have any space in language teaching? Does this variety of language, which displays structural complexities, support learners in fostering language skills? How can such language departed from usual variety support present approach/method of language teaching (although focus is in pedagogy) in our context? Can such variety be effective for our language learners to achieve the skill of communication in our context where most of them cannot speak using simple English or this variety becomes counter-productive? These are vales of issues around us with reference to English language teaching and learning.

As we observe the aforementioned examples of figures of speech, we can say that these figures of speech present varieties of language use (through metaphor, simile, personification, images, symbols, etc). These rhetorical devices make language colourful, catchy, and present the evocation of appeal, and emphasis, etc. As our language learners are familiar to such variety of language, they can compare these varieties with the usual pattern(s) of language. They will point out the example of usual pattern and rearranged pattern or deviated pattern of language. As a result, such variety can develop language awareness in them.

The figures of speech: metaphor and simile have the use of two diversely distinctive objects or vehicles. The meaning of a text comes out through the comparison between them. Such patterns of language do not only display the variety of language use but also become an example of motivating language. Similarly, the use of irony, satire, paradox, exaggeration, etc. can provide the learners with the space for discussion, critical thinking and creative writing. It is not exaggeration to say that the figures of speech: simile, anaphora, refrain, oxymoron, conceit, etc. display motivating language and are useful in developing language acquisition and in creating conducive environment.

\section{About the author \\ Mr. Regmi is Associate Professor of English Education at MahendraRatna Campus Tahachal, Kathmandu. He has authored many textbooks and references beside dozens of research and academic articles in national and international journals on different aspects/ subjects of ELT. His interest lies on literature, literature in language teaching, and teacher training.}

\section{References}

Abrams, M. H., \& Harpham (2005). A glossary of literary terms. USA: Thomson Higher Education

Collie, J., \& Slatter, S. (2009). Literature in the language classroom. Cambridge: Cambridge University Press.

Cudden, J. A. (1982). Dictionary of literary terms and literary theory. Harmondsworth: Penguin

Gautam, K. R. (2014). Figures of speech in Flax-Golden tales. An unpublished M.Ed. thesis. Sapta Gandaki Campus, T.U.

Gray M. (2003). A dictionary of literary terms. India: Pearson Education Limited.

Klarer, M. (2004). An introduction to literary studies. London: Rontledge

Nayar, P. K, (2009). A short history of English literature. Cambridge: Cambridge University Press.

Throad, A. (2004). Poetry and minor forms of English literature. Place: Oxford: Oxford University Press. 